\title{
Phenotypic Correlations and Integration of Nitrogen, Potassium and Press Mud Fertilizers in Relation to Sugarcane Yield and Quality
}

\author{
Anwar H. Sasy and Farrag F.B. Abu-Ellail
}

\begin{abstract}
The present work was carried out at Mallawi Agricultural Research Station, El-Minya Governorate, Egypt (latitude of $28^{\circ} 10^{\prime} \mathrm{N}$, longitude of $30^{\circ} 7^{\prime} \mathrm{E}$ and altitude of $55 \mathrm{~m}$ above sea level) in 2017/2018 and 2018/2019 seasons to study the influence of nitrogen, potassium as inorganic fertilizers and press mud as an organic fertilizer on yield and quality of sugarcane variety G.2003-47 (Giza 3). The field experimental work was carried out in a randomized complete blocks design in a split-split plot arrangement in three replications in both seasons. The results showed that the application of 4 tons of press mud/fed significantly increased plant length, diameter, number of millable canes/fed, stalk weight, cane and sugar yields/fed, as well as brix, sucrose and sugar recovery percentages in both seasons. Increasing nitrogen levels from 150 up to $210 \mathrm{~kg} \mathrm{~N} /$ fed resulted in a significant increase in stalk height, diameter, weight, number of millable canes cane and sugar yields/fed, as well as brix, sucrose, purity and sugar recovery percentages in both seasons. Applying $48 \mathrm{~kg} \mathrm{~K} \mathrm{~K}_{2} \mathrm{O} / \mathrm{fed}$ resulted in a significant increase in cane length, diameter, number of millable canes, stalk weight and cane and sugar yields/fed, as well as brix, sucrose and sugar recovery percentages in both seasons. The correlation analysis showed that the stalk diameter, number of stalks per meter, and weight of the cane contributed most to cane yield at the harvest.
\end{abstract}

Keywords: sugarcane, correlations, press mud, nitrogen, potassium, yield and quality

\section{INTRODUCTION}

Sugarcane is a robust, tillering, and perennial crop. It occupies the soil for more than 5 years. It is considered one of the most efficient $\mathrm{C} 4$ plants in utilizing water, $\mathrm{CO} 2$, and solar radiation in producing a great amount of dry matter. Meanwhile, it depletes tremendous amounts of macro and microelements from the soil. Moreover, occupying the soil so a long period of time harms the soil environment, with respect to aeration, drainage, texture, and water holding capacity. Therefore, this work was conducted aiming at using press mud, having some advantages, as an organic source of nutrients and as a soil amendment, in combination with inorganic nitrogen and potassium fertilizers in sugarcane fertilization.

DOI: $10.21608 / A S E J A I Q J S A E .2021 .145912$

${ }^{1}$ Sugar Crops Research Institute; Agricultural Research Center, Egypt

Corresponding author: Farrag_abuellail@yahoo.com

Received December 06, 2020, Accepted January 30, 2021
Press mud or filter cake, a by-product waste after sugar extraction in sugar factories mills, is delicate, spongy, amorphous, and dark brown stuff. It contains fiber, coagulated colloids, including cane wax, albuminoids, inorganic salts, and dirt particles (Ghulam et al., 2010). Press mud (PM) is organic effluents from sugar factories used to supply nutrient-rich, high-quality organic manure. It also includes plant growth regulators, auxins, enzymes, vitamins, and hormones resulting in maintaining the tilth, fertility, and productivity of agricultural soils (Solaimalai et al., 2001). They also protect the soils from wind and water erosion, thus preventing nutrient losses through runoff and leaching. Press mud or filter cake is one of the important organic wastes capable of providing a sufficient amount of plant nutrients due to its favorable effects on soil texture, structure, organic matter contents, water holding capacity, and aeration of soil (Ghulam et al., 2010). Santos et al., (2010) Pakkiyappan and Saminathan (1999) suggested that application of press mud at 37.5 ton/ha to sugarcane grown on tannery effluent polluted soils of Coimbatore improved the quality of sugarcane. Application of press mud significantly increased brix, sucrose and commercial cane sugar percent (CCS). Press mud application increased sugar yield by $78.5 \%$ over the control. Kalaimani Giridharan (2001) reported that the tiller population and number of millable canes also exhibited the same trend. Yield differences between press mud soil than non-press mud soil ranged from 4 to 20 tons/ha.

It is known that nitrogen has a close relationship with yield and its components, where it plays a direct role in the growth behavior and juice quality of sugar cane. Nitrogen unites with carbonic compounds to produce different organic compounds like chlorophyll, protoplasm, proteins, nucleic acids, vitamins and enzymes. Nitrogen is responsible for growth and development of all living tissues of cane plants. Regarding nitrogen fertilization effect, Mokadem et al., (2008) revealed that increasing $\mathrm{N}$ levels attained positive and significant effects on stalk height, millable canes/fed, cane yield/fed, sugar yield/fed and sugar recovery\%. El-Geddawy et al., (2012) found that increasing $\mathrm{N}$ levels from 170 to $230 \mathrm{~kg} \mathrm{~N} /$ fed produced 
higher values of stalk height, stalk diameter, stalk fresh weight, millable canes/fed, cane and sugar yields, as well as brix $\%$, sucrose $\%$ and sugar recovery $\%$. Neana and Abd El-Hak (2014) concluded that stalk length and diameter, cane and sugar yields and sucrose \% significantly increased by increasing $\mathrm{N}$ levels from 140 up to $200 \mathrm{~kg} \mathrm{~N} / \mathrm{fed}$ in both seasons. Abd El-Aal et al., (2015) reported that increasing $\mathrm{N}$ fertilization levels from 180 to 210 and $240 \mathrm{~kg} \mathrm{~N} /$ fed resulted in a significant increase in millable diameter and cane yield of sugarcane. On the contrary, sucrose and sugar recovery percentages significantly decreased. Bekheet and Abd El-Aziz (2016) found that raising N fertilization level from 180 to $220 \mathrm{~kg} \mathrm{~N} /$ fed led to a significant increase in cane stalk height, millable diameter, number of millable canes, cane and sugar yields/fed. Santos et al., (2010) added filter cake at 0, $0.5,1.0,2.0$ and 4.0 tons/ha and phosphorus fertilizer doses of $0,50,100$ and $200 \mathrm{~kg} \mathrm{P}_{2} \mathrm{O}_{5} / \mathrm{ha}$. They found that stalk yield and tillering were influenced by the filter cake rates applied to the soil. Abd-El-Kader (2017) found that number of millable canes /fed, single millable cane weight, length and stalk diameter, brix, sucrose, sugar recovery as well as cane and sugar yields increased significantly by the applied filter cake with NPK. Santos et al., (2014) found that supplying sugarcane with a combination of 1.0 and $2.0 \mathrm{mg}$ with 100 to $200 \mathrm{~kg} / \mathrm{ha}$ soluble phosphate gave higher stalk and sugar yields Girma (2015) indicated that the main effect of filter cake and the interaction effect of filter cake by mineral fertilizer were highly significant for cane and sugar yields, while the main effect of mineral fertilizer was not significant. He cleared that the application of filter cake highly improved nutritional quality.

The study of the correlation between phenotypic characteristics may reflect biological processes of significant evolutionary value, a correlation may result from genetic, functional, and physiological or developmental traits (Wagner and Schwenk, 2000). Falconer (1989), meanwhile, suggested that the interaction between two or more characters is due to the action or linkage of apheliotropic genes. Abu-Ellail et al., (2019) found that it is important to study the characteristics of sugarcane associated with yield, also reported that crop cycles had a negative effect on cane and sugar yields. The phenotypic association between cane yield and its components, was demonstrated by Abu-Ellail et al., (2017), over the seasons, stalk diameter, stalk weight, and the number of stalks/fed were extremely important in the positive direction. The aim of this study was to find out the appropriate levels of nitrogen, potassium integrated with press mud to get the highest yield and quality traits of sugarcane. Also to estimate the correlations among yield and quality traits.

\section{MATERIALS AND METHODS}

Two field experiments were carried out at Mallawi Research Station, El-Minia Governorate (latitude of $28^{\circ}$ $10^{\prime} \mathrm{N}$, longitude of $30^{\circ} 75^{\prime} \mathrm{E}$ and altitude of $55 \mathrm{~m}$ above sea level) in 2017/2018 and 2018/2019 seasons to study the effect of nitrogen, potassium and press mud on yield and quality of sugar cane under conditions of El-Minia Governorate. The field experimental work was carried out in a randomized complete block design using splitsplit plot arrangement in three replications in both seasons. Press mud levels $(0,2$ and 4 ton/fed) were allocated at random in the main plots. Nitrogen fertilization levels (150, 180 and $210 \mathrm{~kg} \mathrm{~N} / \mathrm{fed}$ ) were distributed randomly in the sub plots, while potassium levels ( 24 and $48 \mathrm{~kg} \mathrm{~K}_{2} \mathrm{O} / \mathrm{fed}$ ) were applied in the subsub plots of press mud was applied during land preparation. Nitrogen fertilizer was applied in the form urea $46 \%$ and divided into equal doses; after 60 days from planting and 30 days later, while potassium fertilizer was added with the second nitrogen dose. The experimental unit area was $35 \mathrm{~m}^{2}$ (1/120 fed) including 5 rows of $1 \mathrm{~m}$ and $7 \mathrm{~m}$ in length. Sugarcane G. 2003-47 (commercially called Giza 3 ) was planted during the $1^{\text {st }}$ week of March and harvested after 12 months in both seasons, using the dry method of planting with 3budded cane cuttings, which were drilled in each furrow. The mechanical and chemical properties of the upper $40 \mathrm{~cm}$ of the experimental soil are presented in (Table 1), Also, the chemical composition of the filter cake used in the experiments is presented in Table 2. 
Table 1. Soil properties of the experimental sites in 2017-2018 and 2018-2019 seasons

\begin{tabular}{ccc}
\hline Soil property & $\mathbf{2 0 1 7 / 2 0 1 8}$ & $\mathbf{2 0 1 8} / \mathbf{2 0 1 9}$ \\
\hline Particule size distribution : & & \\
Sand\% & 55.34 & 51.57 \\
$\mathrm{Silt} \%$ & 29.34 & 26.30 \\
Clay\% & 15.32 & 22.13 \\
Soil texture & \multicolumn{2}{c}{ Sandy loam } \\
\hline $\mathrm{OM}(\%)$ & 0.21 & 0.29 \\
\hline Available $\mathrm{Nitrogen} \mathrm{mg} / \mathrm{kg}$ soil $_{\text {Available } \mathrm{P}_{2} \mathrm{O}_{5} \mathrm{mg} / \mathrm{kg} \text { soil }}$ & 0.19 & 0.22 \\
Available $\mathrm{K}_{2} \mathrm{O}$ mg/kg soil & 2.91 & 3.74 \\
$\mathrm{EC}(\mathrm{dS} / \mathrm{m})$ & 0.89 & 0.93 \\
$\mathrm{pH}$ at $(1: 2.5)$ soil : water suspension & 0.23 & 0.21 \\
& 7.6 & 7.5 \\
\hline $\mathrm{Mg}^{++}$ & Cations $(\mathrm{meq} / \mathrm{l})$ & 0.22 \\
$\mathrm{Na}^{+}$ & 0.26 & 1.13 \\
$\mathrm{Ca}^{++}$ & 1.19 & 0.48 \\
$\mathrm{~K}^{+}$ & 0.51 & 0.12 \\
& 0.14 & 0.22 \\
$\mathrm{HCO}^{-}$ & Anions $(\mathrm{meq} / \mathrm{l})$ & 0.75 \\
$\mathrm{Cl}^{-}$ & 0.29 & 0.98 \\
$\mathrm{SO}^{-}$ & 0.85 & \\
\hline
\end{tabular}

Table 2. Chemical composition of press mud used in the experiments

\begin{tabular}{|c|c|c|c|}
\hline \multicolumn{2}{|c|}{ Season } & $2017 / 2018$ & $2018 / 2019$ \\
\hline \multirow{3}{*}{ Macro elements (\%) } & Total N (\%) & 2.75 & 2.96 \\
\hline & Total P (\%) & 1.43 & 1.47 \\
\hline & Total K (\%) & 0.66 & 0.72 \\
\hline \multirow{4}{*}{ Micro elements $(\mathrm{mg} / \mathrm{kg})$} & $\mathrm{Fe}$ & 29.5 & 33.3 \\
\hline & Mn & 279 & 287 \\
\hline & $\mathrm{Zn}$ & 105 & 109 \\
\hline & $\mathrm{Cu}$ & 129 & 132 \\
\hline \multicolumn{2}{|c|}{ Organic matter \% } & 28.7 & 30.5 \\
\hline \multicolumn{2}{|c|}{ Organic C $\%$} & 19.1 & 21.2 \\
\hline \multicolumn{2}{|c|}{ pH (1:5) Susp. } & 7.61 & 7.82 \\
\hline \multicolumn{2}{|c|}{$\mathrm{EC}(\mathrm{dS} / \mathrm{m})(1: 5)$} & 1.01 & 1.03 \\
\hline \multicolumn{2}{|c|}{$\mathrm{C} / \mathrm{N}$ ratio } & $10: 3$ & $13: 8$ \\
\hline \multicolumn{2}{|c|}{ Humidity $\%$} & 51.0 & 52.2 \\
\hline
\end{tabular}

At harvest, the following data were recorded:

1. Millable cane length $(\mathrm{cm})$.

2. Millable cane diameter $(\mathrm{cm})$.

3. Millable cane weight $(\mathrm{kg})$.

4. Number of millable canes in (thousand/fed) was counted in one square meter, then converted into a number per feddan $\left(4200 \mathrm{~m}^{2}\right)$.

\section{Juice quality characteristics:}

At harvest, a sample of 20 millable canes from each treatment was taken at random, cleaned and crushed and analyzed to determine the following traits:
1. Brix\% was determined in the laboratory using "Brix Hydrometer" according to the method described by "The Chemical Control Lab" of Sugar and Integrated Industries Company (Anonymous, 1981).

2. Sucrose \% was determined using "Sacharemeter" according to A.O.A.C. (1995).

3. Juice purity\% was calculated using the following equation:

Purity $\%=($ sucrose $\% \times 100) / b r i x \%$

4. Sugar recovery percentage was calculated as follows:

Sugar recovery $\%=$ richness $\%$ x purity $\% / 100$ 
Where: richness was estimated using the following equation:

Where Richness $=($ sucrose in 100 grams $\mathrm{x}$ factor $) /$ 100.

Factor $=100-[$ fiber $\%+$ physical impurities

$\%+$ percent water free from sugar].

\section{Cane and sugar yields:}

1. Cane yield/fed (ton) was counted from the weight of the three middle rows of each plot $(\mathrm{kg})$ and converted into ton/fed.

2. Sugar yield/fed (ton) was estimated according to the following equation:

Sugar yield/fed (ton) = cane yield/fed (ton) $\mathrm{x}$ sugar recovery\%.

\section{Statistical analysis:}

The collected data were statistically analyzed according to Gomez and Gomez (1984) using the computer "MSTAT-c" statistical analysis package by Freed et al., (1989). The least significant differences (LSD) at 0.05 level of probability were calculated to compare the differences among treatment means. SPSS version 10 was used for assessing the magnitudes of correlation among variables (Spearman's Correlation). Phenotypic correlation coefficients were calculated among all the traits according to (Falconer, 1989).

\section{RESULTSAND DISCUSSION}

\section{Millable cane length and diameter:}

The results in Table 3 indicated that increasing quantity of press mud supplied to sugarcanes from 2 to 4 tons/fed increased stalk height and diameter of sugar cane significantly by 6.81 and $16.83 \mathrm{~cm}$ and 0.03 and $0.06 \mathrm{~cm}$ compared to the check treatment (without press mud), respectively, in the $1^{\text {st }}$ season, corresponding to 8.82 and $18.16 \mathrm{~cm}$ and 0.03 and $0.04 \mathrm{~cm}$, in the $2^{\text {nd }}$ one. These results could be referred that press mud contains some organic matter and nutrients (Table 2), which had a positive role in sugarcane growth. This finding is in accordance with those reported by Kumar and Verma (2002), Shankaraiah and Murthy (2005) and Abd-ElKader (2017).

Data in Table 3 showed that increasing nitrogen fertilization levels from 180 to 210 increased millable cane length significantly by 8.40 and $22.43 \mathrm{~cm}$, respectively in the $1^{\text {st }}$ season, corresponding to 11.56 and $24.75 \mathrm{~cm}$, in the $2^{\text {nd }}$ one, as compared with that recorded when $\mathrm{N}$-fertilizer was given at $150 \mathrm{~kg} \mathrm{~N} / \mathrm{fed}$. Likewise, an increase of 0.02 and $0.05 \mathrm{~cm}$ in millable cane diameter was detected in the $1^{\text {st }}$ season, corresponding to 0.03 and $0.05 \mathrm{~cm}$ in the $2^{\text {nd }}$ one. These results fairly proved that supplying sugarcanes with 210 $\mathrm{kg}$ nitrogen was physiologically needed for better growth and efficient performance of plants to attain their highest potential, compared to those given the lowest $\mathrm{N}$-level. These results are in harmony with those reported by and Nassar et al., (2005), Ahmed and ElShafai (2007), Mokadem et al., (2008), El-Gedawwy et al., (2012), Neana \& Abd El-Hak (2014), Abd El-Aal et al., (2015) and Bekheet and Abd El-Aziz (2016).

Results in Table 3 showed that increasing levels of potassium fertilizer level from 24 to $48 \mathrm{~kg} / \mathrm{fed} \mathrm{K}_{2} \mathrm{O}$ resulted in significant increases in millable cane length and diameter in both seasons. Applying $48 \mathrm{~kg} \mathrm{~K}_{2} \mathrm{O} / \mathrm{fed}$ gave higher values of these two traits. These results may be due to the role of potassium in the meristemic activity of plant tissues. These results are similar to those obtained by El-Sogheir et al., (2003), Osman et al., (2004) and El-Sayed et al., (2005).

The interaction between nitrogen levels and potassium fertilizers $(\mathrm{N} \times \mathrm{K})$ had a significant influence on stalk length in the $1^{\text {st }}$ season only. The longest stalk was recorded when sugarcane was fertilized with 210 $\mathrm{kg} \mathrm{N} / \mathrm{fed}+48 \mathrm{~kg} \mathrm{~K}_{2} \mathrm{O} / \mathrm{fed}$. The interaction between nitrogen levels and press mud (N x PM) significantly affected millable length in the $2^{\text {nd }}$, and millable diameter in the $1^{\text {st }}$ one. The interaction between $\mathrm{K} x$ PM had a significant effect on millable length in both seasons and diameter in the $1^{\text {st }}$ one. The longest stalk by adding potassium at $48 \mathrm{~kg} \mathrm{~K} \mathrm{~K}_{2} \mathrm{O} /$ fed 4 tons press $\mathrm{mud} / \mathrm{fed}$ in both seasons. The $2^{\text {nd }}$ order interactions among the three studied factors had a significant effect on millable length and diameter in the $1^{\text {st }}$ season only. Fertilizing sugar cane with $210 \mathrm{~kg} \mathrm{~N}+48 \mathrm{~kg} \mathrm{~K}_{2} \mathrm{O}+4$ tons press $\mathrm{mud} / \mathrm{fed}$ gave the highest millable length and diameter in the $1^{\text {st }}$ season.

\section{Millable cane weight and number:}

Data in Table 4 manifested that increasing level of press mud supplied to sugarcanes from 2 to 4 tons/fed increased stalk weight and a number of millable canes/fed by ( 0.03 and $0.05 \mathrm{~kg} / \mathrm{plant})$ and $(0.6$ and 1.14 thousand canes/fed) compared to that recorded by canes left without press mud, respectively, in the $1^{\text {st }}$ season, corresponding to $(0.02$ and $0.04 \mathrm{~kg})$ and $(0.64$ and 1.2 thousand canes/fed) in the $2^{\text {nd }}$ season. These results could be referred to that the press mud added some organic matter and nutrients (Table 2) to the soil used by cane plants. These findings in agreement with those obtained by Kalaimani and Giridharan (2001), Kumar and Verma (2002), Shankaraiah and Murthy (2005) and Abd-El-Kader (2017). 
Table 3. Effect of press mud, nitrogen, potassium levels and their interactions on millable length and diameter in 2017/2018 and 2018/2019 seasons

\begin{tabular}{|c|c|c|c|c|c|c|c|c|c|c|c|c|c|}
\hline \multirow{4}{*}{$\begin{array}{c}\text { Traits } \\
\text { Press } \\
\text { mud/fed, } \\
\text { ton } \\
(\text { PM) }\end{array}$} & \multirow{4}{*}{$\begin{array}{c} \\
N \\
\text { level } \\
(\mathbf{k g} \\
\text { /fed) }\end{array}$} & \multicolumn{6}{|c|}{ Millable cane length $(\mathrm{cm})$} & \multicolumn{6}{|c|}{ Millable cane diameter $(\mathrm{cm})$} \\
\hline & & \multicolumn{3}{|c|}{ 2017/2018 season } & \multicolumn{3}{|c|}{ 2018/2019 season } & \multicolumn{3}{|c|}{ 2017/2018 season } & \multicolumn{3}{|c|}{ 2018/2019 season } \\
\hline & & \multicolumn{2}{|c|}{$\begin{array}{c}\text { K level } \\
\text { (kg /fed) }\end{array}$} & \multirow[t]{2}{*}{ Mean } & \multicolumn{2}{|c|}{$\begin{array}{c}\text { K level } \\
\text { (kg/fed) }\end{array}$} & \multirow[t]{2}{*}{ Mean } & \multicolumn{2}{|c|}{$\begin{array}{l}\text { K level } \\
\text { (kg /fed) }\end{array}$} & \multirow[t]{2}{*}{ Mean } & \multicolumn{2}{|c|}{$\begin{array}{c}\text { K level } \\
\text { (kg/fed) }\end{array}$} & \multirow[t]{2}{*}{ Mean } \\
\hline & & 24 & 48 & & 24 & 48 & & 24 & 48 & & 24 & 48 & \\
\hline \multirow{3}{*}{0} & 150 & 250.16 & 257.45 & 253.81 & 249.85 & 255.24 & 252.55 & 2.47 & 2.49 & 2.48 & 2.48 & 2.53 & 2.51 \\
\hline & 180 & 258.09 & 265.69 & 261.89 & 262.51 & 268.54 & 265.53 & 2.51 & 2.54 & 2.53 & 2.52 & 2.54 & 2.53 \\
\hline & 210 & 269.83 & 279.94 & 274.89 & 272.01 & 281.22 & 276.62 & 2.54 & 2.61 & 2.58 & 2.56 & 2.57 & 2.57 \\
\hline \multicolumn{2}{|c|}{ Mean } & 259.36 & 265.26 & 262.31 & 261.56 & 266.64 & 264.10 & 2.51 & 2.55 & 2.53 & 2.52 & 2.55 & 2.53 \\
\hline \multirow{3}{*}{2} & 150 & 259.35 & 261.25 & 260.30 & 256.50 & 262.84 & 259.67 & 2.51 & 2.54 & 2.53 & 2.51 & 2.55 & 2.53 \\
\hline & 180 & 265.05 & 271.06 & 268.06 & 270.75 & 278.99 & 274.87 & 2.51 & 2.62 & 2.57 & 2.54 & 2.61 & 2.58 \\
\hline & 210 & 277.71 & 289.44 & 283.58 & 283.41 & 289.75 & 286.58 & 2.56 & 2.65 & 2.61 & 2.59 & 2.68 & 2.64 \\
\hline \multicolumn{2}{|c|}{ Mean } & 267.37 & 273.28 & 270.33 & 270.22 & 277.19 & 273.71 & 2.53 & 2.60 & 2.57 & 2.55 & 2.61 & 2.58 \\
\hline \multirow{3}{*}{4} & 150 & 270.11 & 275.19 & 272.65 & 271.39 & 274.86 & 273.13 & 2.54 & 2.57 & 2.56 & 2.54 & 2.61 & 2.58 \\
\hline & 180 & 273.62 & 281.25 & 277.44 & 275.55 & 283.74 & 279.65 & 2.56 & 2.65 & 2.61 & 2.56 & 2.64 & 2.60 \\
\hline & 210 & 285.31 & 296.71 & 291.01 & 292.29 & 300.51 & 296.40 & 2.58 & 2.72 & 2.65 & 2.62 & 2.73 & 2.68 \\
\hline \multicolumn{2}{|c|}{ Mean } & 276.35 & 284.38 & 280.37 & 279.74 & 286.37 & 283.06 & 2.56 & 2.65 & 2.60 & 2.57 & 2.66 & 2.62 \\
\hline \multirow{3}{*}{$\begin{array}{c}\text { Mean of } \\
(\mathbf{N} \times \mathbf{K})\end{array}$} & 150 & 259.87 & 261.57 & 260.72 & 259.25 & 264.31 & 261.78 & 2.51 & 2.53 & 2.52 & 2.51 & 2.56 & 2.54 \\
\hline & 180 & 265.59 & 272.67 & 269.13 & 269.60 & 277.09 & 273.35 & 2.53 & 2.60 & 2.57 & 2.54 & 2.60 & 2.57 \\
\hline & 210 & 277.62 & 288.70 & 283.16 & 282.57 & 290.49 & 286.53 & 2.56 & 2.66 & 2.61 & 2.59 & 2.66 & 2.63 \\
\hline \multicolumn{2}{|c|}{ Mean of K } & 267.69 & 274.31 & & 270.51 & 276.73 & & 2.53 & 2.60 & & 2.55 & 2.61 & \\
\hline \multicolumn{14}{|c|}{ LSD at 0.5 level for: } \\
\hline \multicolumn{4}{|c|}{ Nitrogen levels (N) } & 2.16 & & & 3.87 & & & 0.02 & & & 0.02 \\
\hline \multicolumn{4}{|c|}{ Potassium levels (K) } & 1.71 & & & 2.19 & & & 0.01 & & & 0.01 \\
\hline \multicolumn{4}{|c|}{ Press mud (PM) } & 2.31 & & & 1.24 & & & 0.01 & & & 0.03 \\
\hline$(\mathrm{N}) \times(\mathrm{K})$ & & & & 3.11 & & & NS & & & NS & & & NS \\
\hline$(\mathrm{N}) \times(\mathrm{PM}$ & & & & NS & & & 2.09 & & & 0.03 & & & 0.02 \\
\hline$(\mathrm{K}) \times((\mathrm{PN}$ & & & & 2.99 & & & 1.63 & & & 0.01 & & & 0.02 \\
\hline$(\mathrm{N}) \mathrm{x}(\mathrm{K}) \mathrm{x}$ & PM) & & & 5.23 & & & NS & & & 0.01 & & & 0.01 \\
\hline
\end{tabular}

Results in Table 4 showed that increasing nitrogen fertilization levels from 180 to 210 led to a significant increase in the single stalk weight and a number of millable canes/fed amounted to $(0.04$ and $0.07 \mathrm{~kg} /$ plant $)$ and (0.39 and.0.81 thousand canes/fed), respectively in the $1^{\text {st }}$ season, corresponding to $(0.04$ and $0.09 \mathrm{~kg})$ and ( 0.52 and 0.84 thousand canes/fed $)$, in the $2^{\text {nd }}$ one, successively as compared with those recorded when sugarcane was given $150 \mathrm{~kg} \mathrm{~N} / \mathrm{fed}$. These results may be due to the role of nitrogen in promoting tillering, canopy development and the stalk formation. These results are in line with those reported by Nassar et al., (2005), Ahmed and El-Shafai (2007), Mokadem et al., (2008), El-Gedawwy et al., (2012) and Bekheet and Abd El-Aziz (2016). Supplying sugarcane with $48 \mathrm{~kg}$ $\mathrm{K}_{2} \mathrm{O} /$ fed gave the highest stalk weight and a number of millable canes/fed in both seasons. These results may be due to the vital role of potassium in dry matter translocation from leaves to be stored in stalks and hence improving their weights. These results are similar to those obtained by El-Sogheir et al., (2003), Osman et al., (2004), El-Sayed et al., (2005) and Abd-El-Kader (2017).

The interaction of $\mathrm{N}_{\mathrm{x}} \mathrm{K}$ had a significant influence on stalk weight in the $2^{\text {nd }}$ season and the number of millable canes/fed in the $1^{\text {st }}$ one. The heaviest stalks and the greatest number of millable canes/fed resulted from sugarcane plants fertilized with $210 \mathrm{~kg} \mathrm{~N} / \mathrm{fed}+48 \mathrm{~kg}$ $\mathrm{K}_{2} \mathrm{O} /$ fed. The interaction between levels of nitrogen fertilizer and press mud had a significant effect on stalk weight in both seasons, while the number of millable canes/fed was influenced by the same interaction in the $2^{\text {nd }}$ season.

Stalk weight has significantly affected the interaction between $\mathrm{K}$ and $\mathrm{PM}$ in both seasons. The highest mean value of stalk weight by adding $48 \mathrm{~kg}$ $\mathrm{K}_{2} \mathrm{O}$ potassium with 4 tons of press mud /fed, in both seasons. The number of millable cane/fed was significantly affected by an interaction between $\mathrm{K}$ and $\mathrm{PM}$ in the $1^{\text {st }}$ season. The highest number of millable canes/fed was recorded by applying $48 \mathrm{~kg} \mathrm{~K}_{2} \mathrm{O}$ and 4 tons of press mud/fed. The $2^{\text {nd }}$ order interaction among 
Table 4. Effect of press mud, nitrogen, potassium levels and their interactions on millabe cane number (thousand/fed) and stalk weight (kg/stalk) 2017/2018 and 2018/2019 seasons

\begin{tabular}{|c|c|c|c|c|c|c|c|c|c|c|c|c|c|}
\hline \multirow{4}{*}{\begin{tabular}{l}
\multicolumn{1}{c}{ Traits } \\
Press \\
mud/fed, \\
ton \\
$($ PM)
\end{tabular}} & \multicolumn{7}{|c|}{ Millable cane number/fed (thousand) } & \multicolumn{6}{|c|}{ Millable cane weight $(\mathrm{kg})$} \\
\hline & \multirow{3}{*}{$\begin{array}{c}\mathrm{N} \\
\text { level } \\
\text { (kg } \\
\text { /fed) }\end{array}$} & \multicolumn{3}{|c|}{ 2017/2018 season } & \multicolumn{3}{|c|}{$2018 / 2019$ season } & \multicolumn{3}{|c|}{ 2017/2018 season } & \multicolumn{3}{|c|}{$2018 / 2019$ season } \\
\hline & & \multicolumn{2}{|c|}{$\begin{array}{c}\text { K level } \\
\text { (kg /fed) }\end{array}$} & \multirow[t]{2}{*}{ Mean } & \multicolumn{2}{|c|}{$\begin{array}{c}\text { K level } \\
\text { (kg /fed) }\end{array}$} & \multirow[t]{2}{*}{ Mean } & \multicolumn{2}{|c|}{$\begin{array}{c}\text { K level } \\
\text { (kg/fed) }\end{array}$} & \multirow[t]{2}{*}{ Mean } & \multicolumn{2}{|c|}{$\begin{array}{c}\text { K level } \\
\text { (kg/fed) }\end{array}$} & \multirow[t]{2}{*}{ Mean } \\
\hline & & 24 & 48 & & 24 & 48 & & 24 & 48 & & 24 & 48 & \\
\hline \multirow{3}{*}{$\mathbf{0}$} & 150 & 40.19 & 40.13 & 40.16 & 39.76 & 40.18 & 39.97 & 1.17 & 1.20 & 1.19 & 1.16 & 1.18 & 1.17 \\
\hline & 180 & 40.26 & 40.62 & 40.44 & 40.39 & 40.81 & 40.60 & 1.22 & 1.23 & 1.23 & 1.21 & 1.22 & 1.22 \\
\hline & 210 & 40.69 & 41.00 & 40.85 & 40.73 & 41.03 & 40.88 & 1.25 & 1.26 & 1.26 & 1.25 & 1.25 & 1.25 \\
\hline \multirow{2}{*}{ Mean } & & 40.38 & 40.60 & 40.49 & 40.44 & 40.68 & 40.56 & 1.21 & 1.23 & 1.22 & 1.21 & 1.22 & 1.21 \\
\hline & 150 & 40.66 & 40.84 & 40.75 & 40.55 & 40.86 & 40.71 & 1.20 & 1.21 & 1.21 & 1.19 & 1.21 & 1.20 \\
\hline \multirow[t]{2}{*}{2} & 180 & 41.88 & 41.92 & 41.90 & 40.94 & 41.42 & 41.18 & 1.25 & 1.28 & 1.27 & 1.22 & 1.25 & 1.24 \\
\hline & 210 & 42.33 & 42.71 & 42.52 & 41.31 & 41.64 & 41.48 & 1.33 & 1.35 & 1.34 & 1.34 & 1.36 & 1.35 \\
\hline \multicolumn{2}{|c|}{ Mean } & 41.62 & 41.76 & 41.69 & 40.93 & 41.31 & 41.12 & 1.26 & 1.28 & 1.27 & 1.25 & 1.27 & 1.26 \\
\hline \multirow{3}{*}{4} & 150 & 41.92 & 41.83 & 41.88 & 40.97 & 41.52 & 41.25 & 1.23 & 1.25 & 1.24 & 1.20 & 1.24 & 1.22 \\
\hline & 180 & 42.42 & 42.91 & 42.67 & 41.46 & 42.94 & 42.20 & 1.26 & 1.30 & 1.28 & 1.23 & 1.28 & 1.26 \\
\hline & 210 & 42.91 & 42.21 & 42.56 & 41.92 & 43.26 & 42.59 & 1.41 & 1.38 & 1.40 & 1.39 & 1.41 & 1.40 \\
\hline \multicolumn{2}{|c|}{ Mean } & 42.42 & 42.32 & 42.37 & 41.45 & 42.57 & 42.01 & 1.30 & 1.31 & 1.31 & 1.27 & 1.31 & 1.29 \\
\hline \multirow{4}{*}{$\begin{array}{c}\text { Mean of } \\
(\mathbf{N} \times \mathbf{K}) \\
\text { Mean }\end{array}$} & 150 & 40.92 & 40.89 & 40.91 & 40.43 & 40.85 & 40.64 & 1.20 & 1.22 & 1.21 & 1.18 & 1.21 & 1.20 \\
\hline & 180 & 41.52 & 41.82 & 41.67 & 40.93 & 41.72 & 41.33 & 1.24 & 1.27 & 1.26 & 1.22 & 1.25 & 1.24 \\
\hline & 210 & 41.98 & 41.97 & 41.98 & 41.32 & 41.98 & 41.65 & 1.33 & 1.33 & 1.33 & 1.33 & 1.34 & 1.33 \\
\hline & & 41.47 & 41.56 & & 40.94 & 41.52 & & 1.26 & 1.27 & & 1.24 & 1.27 & \\
\hline \multicolumn{14}{|c|}{ LSD at 0.5 level for: } \\
\hline \multicolumn{4}{|c|}{ Nitrogen levels (N) } & 0.0 & & & & & & & & & 0.003 \\
\hline \multicolumn{4}{|c|}{ Potassium levels $(\mathrm{K})$} & 0.064 & & & 0.039 & & & 0.0 & & & 0.001 \\
\hline \multicolumn{4}{|c|}{ Press mud (PM) } & 0.98 & & & 0.032 & & & 0.003 & & & 0.002 \\
\hline \multicolumn{3}{|l|}{$(\mathrm{N}) \times(\mathrm{K})$} & & 0.105 & & & NS & & & NS & & & 0.001 \\
\hline$(\mathrm{N}) \times(\mathrm{PM}$ & & & & NS & & & 0.065 & & & 0.004 & & & 0.004 \\
\hline$(\mathrm{K}) \times((\mathrm{PN}$ & & & & 0.138 & & & NS & & & 0.003 & & & 0.002 \\
\hline$(\mathrm{N}) \mathrm{x}(\mathrm{K}) \mathrm{x}$ & $(\mathrm{PM})$ & & & NS & & & NS & & & 0.004 & & & 0.005 \\
\hline
\end{tabular}

the three studied factors had a significant influence on millable weight in both seasons. Fertilizing sugar cane with $210 \mathrm{~kg} \mathrm{~N} 48 \mathrm{~kg} \mathrm{~K} 2 \mathrm{O} 4$ tons of press mud/fed gave the highest stalk weight in both seasons.

\section{Juice quality traits:}

Data in Tables 5 and 6 cleared that increasing level of press mud supplied to sugarcanes from 2 up to 4 tons/fed increased brix, sucrose and sugar recovery percentages significantly by $(0.59$ and $1.00 \%),(0.46$ and $0.77 \%)$ and $(0.32$ and $0.53 \%)$ compared to those recorded by canes left without press mud, respectively, in the $1^{\text {st }}$ season, corresponding to $(0.56$ and 0.87$),(0.35$ and $0.66 \%)$ and $(0.21$ and $0.45 \%)$ in the $2^{\text {nd }}$ season. These findings may be attributed to that press mud is a good source of organic matter, NPK and important micronutrients (Table 2). Moreover, it may contribute to improving fertility, productivity and other physical properties of agricultural soils, which positively reflected on the previous quality characteristics. These results are in line with those reported by Pakkiyappan and Saminathan (1999), Kumar and Verma (2002) and Abd- El-Kader (2017). However, purity \% was not significantly affected by the levels of press mud, in both seasons.

The results showed that nitrogen levels had a significant effect on juice quality traits under study, in both seasons except purity\% in the $2^{\text {nd }}$ season. Gradual increases in brix, sucrose and sugar recovery percentages values were noticed as nitrogen rate increased from 150 up to $210 \mathrm{~kg} \mathrm{~N} / \mathrm{fed}$, thereafter tended to decrease as nitrogen fertilization level was raised to $210 \mathrm{~kg} \mathrm{~N} / \mathrm{fed}$. Similar results were observed by Nassar et al., (2005), Mokadem et al., (2008), ElGeddawy et al., (2012) and Neana and Abd El-Hak (2014). 
The results in the same Tables showed that increasing the level of potassium from 24 to $48 \mathrm{~kg}$ $\mathrm{K}_{2} \mathrm{O} /$ fed caused a significant increase in the brix, sucrose and sugar recovery percentages in both seasons, and purity $\%$ in the first one. However, increasing $\mathrm{K}$ fertilizer level given to sugarcane from 24 to $48 \mathrm{~kg} / \mathrm{fed}$ decreased purity percentage. These results are in agreement with those mentioned by El-Sogheir et al., (2003), Osman et al. (2004), El-Sayed et al., (2005) and Abd-El-Kader (2017).
The interaction between nitrogen fertilization level and press mud significantly affected brix and sucrose percentages in both seasons as well as purity and sugar recovery percentages in the $1^{\text {st }}$ one. Brix and sucrose percentages were significantly affected by the interaction between levels of potassium and press mud in both seasons, while purity and sugar recovery percentages were significantly influenced by the respective interaction in the $1^{\text {st }}$ season only.

Table 5. Effect of press mud, nitrogen, potassium levels and their interactions on brix and sucrose percentages in 2017/2018 and 2018/2019 seasons

\begin{tabular}{|c|c|c|c|c|c|c|c|c|c|c|c|c|c|}
\hline \multirow{4}{*}{$\begin{array}{c}\text { Traits } \\
\text { Press } \\
\text { mud/fed, } \\
\text { ton } \\
(\text { PM) }\end{array}$} & \multirow{4}{*}{$\begin{array}{c}\mathbf{N} \\
\text { level } \\
\text { (kg } \\
\text { /fed) }\end{array}$} & \multicolumn{6}{|c|}{ Brix \% } & \multicolumn{6}{|c|}{ Sucrose \% } \\
\hline & & \multicolumn{3}{|c|}{ 2017/2018 season } & \multicolumn{3}{|c|}{ 2018/2019 season } & \multicolumn{3}{|c|}{$2017 / 2018$ season } & \multicolumn{3}{|c|}{ 2018/2019 season } \\
\hline & & \multicolumn{2}{|c|}{$\begin{array}{c}\text { K level } \\
\text { (kg /fed) }\end{array}$} & \multirow[t]{2}{*}{ Mean } & \multicolumn{2}{|c|}{$\begin{array}{c}\text { K level } \\
\text { (kg /fed) }\end{array}$} & \multirow[t]{2}{*}{ Mean } & \multicolumn{2}{|c|}{$\begin{array}{c}\text { K level } \\
\text { (kg /fed) }\end{array}$} & \multirow[t]{2}{*}{ Mean } & \multicolumn{2}{|c|}{$\begin{array}{c}\text { K level } \\
\text { (kg /fed) }\end{array}$} & \multirow[t]{2}{*}{ Mean } \\
\hline & & 24 & 48 & & 24 & 48 & & 24 & 48 & & 24 & 48 & \\
\hline \multirow{3}{*}{$\mathbf{0}$} & 150 & 17.18 & 17.45 & 17.32 & 17.54 & 17.84 & 17.69 & 14.13 & 14.33 & 14.23 & 14.54 & 14.79 & 14.67 \\
\hline & 180 & 17.40 & 18.77 & 18.09 & 18.73 & 18.91 & 18.82 & 14.54 & 15.45 & 15.00 & 15.56 & 15.66 & 15.61 \\
\hline & 210 & 18.78 & 19.06 & 18.92 & 19.11 & 19.37 & 19.24 & 15.49 & 15.87 & 15.68 & 15.89 & 16.11 & 16.00 \\
\hline \multirow[t]{2}{*}{ Mean } & & 17.79 & 18.34 & 18.06 & 18.34 & 18.49 & 18.41 & 14.72 & 15.22 & 14.97 & 15.33 & 15.52 & 15.43 \\
\hline & 150 & 18.48 & 18.86 & 18.67 & 18.60 & 18.86 & 18.73 & 15.39 & 15.75 & 15.57 & 15.40 & 15.69 & 15.55 \\
\hline \multirow[t]{2}{*}{2} & 180 & 18.88 & 19.08 & 18.98 & 19.03 & 19.17 & 19.10 & 15.48 & 15.87 & 15.68 & 15.75 & 15.94 & 15.85 \\
\hline & 210 & 19.40 & 19.80 & 19.60 & 19.46 & 19.88 & 19.67 & 16.18 & 16.47 & 16.33 & 15.88 & 16.50 & 16.19 \\
\hline \multirow[t]{2}{*}{ Mean } & & 18.92 & 19.12 & 19.02 & 19.03 & 19.30 & 19.17 & 15.68 & 16.03 & 15.86 & 15.68 & 16.04 & 15.86 \\
\hline & 150 & 18.86 & 19.09 & 18.98 & 18.86 & 19.14 & 19.00 & 15.69 & 15.91 & 15.80 & 15.74 & 15.80 & 15.77 \\
\hline \multirow[t]{2}{*}{4} & 180 & 19.25 & 19.38 & 19.32 & 19.37 & 19.55 & 19.46 & 16.06 & 16.16 & 16.11 & 16.13 & 16.16 & 16.15 \\
\hline & 210 & 19.89 & 20.09 & 19.99 & 19.91 & 20.06 & 19.99 & 16.40 & 16.71 & 16.56 & 16.51 & 16.69 & 16.60 \\
\hline \multicolumn{2}{|c|}{ Mean } & 19.33 & 19.52 & 19.43 & 19.38 & 19.58 & 19.48 & 16.05 & 16.26 & 16.16 & 16.13 & 16.22 & 16.17 \\
\hline \multirow{4}{*}{$\begin{array}{c}\text { Mean of } \\
(\mathbf{N} \times \mathbf{K}) \\
\text { Mean }\end{array}$} & 150 & 18.17 & 18.25 & 18.21 & 18.33 & 18.61 & 18.47 & 15.07 & 15.33 & 15.20 & 15.23 & 15.43 & 15.33 \\
\hline & 180 & 18.51 & 19.08 & 18.79 & 19.04 & 19.21 & 19.13 & 15.36 & 15.83 & 15.59 & 15.81 & 15.92 & 15.87 \\
\hline & 210 & 19.36 & 19.65 & 19.50 & 19.49 & 19.77 & 19.63 & 16.02 & 16.35 & 16.19 & 16.09 & 16.43 & 16.26 \\
\hline & & 18.68 & 18.99 & & 18.92 & 19.12 & & 15.48 & 15.84 & & 15.71 & 15.93 & \\
\hline \multicolumn{14}{|c|}{ LSD at 0.5 level for: } \\
\hline \multicolumn{4}{|c|}{ Nitrogen levels (N) } & 009 & & & 0.02 & & & 0.1 & & & 0.13 \\
\hline \multicolumn{3}{|c|}{ Potassium levels (K) } & & 0.03 & & & $0.03 *$ & & & 0.03 & & & 0.12 \\
\hline \multicolumn{3}{|c|}{ Press mud (PM) } & & 0.02 & & & 0.05 & & & 0.04 & & & 0.10 \\
\hline \multicolumn{3}{|l|}{$(\mathrm{N}) \mathrm{x}(\mathrm{K})$} & & 0.05 & & & 0.07 & & & NS & & & NS \\
\hline$(\mathrm{N}) \times(\mathrm{PM}$ & & & & 0.06 & & & 0.05 & & & 0.05 & & & 0.17 \\
\hline$(\mathrm{K}) \times((\mathrm{PN}$ & & & & 0.04 & & & 0.06 & & & 0.06 & & & 0.16 \\
\hline$(\mathrm{N}) \mathrm{x}(\mathrm{K}) \mathrm{x}$ & $(\mathrm{PM})$ & & & 0.11 & & & 0.08 & & & 0.07 & & & 0.23 \\
\hline
\end{tabular}


Table 6. Effect of press mud, nitrogen, potassium levels and their interactions on purity and sugar recovery percentages in 2017/2018 and 2018/2019 seasons

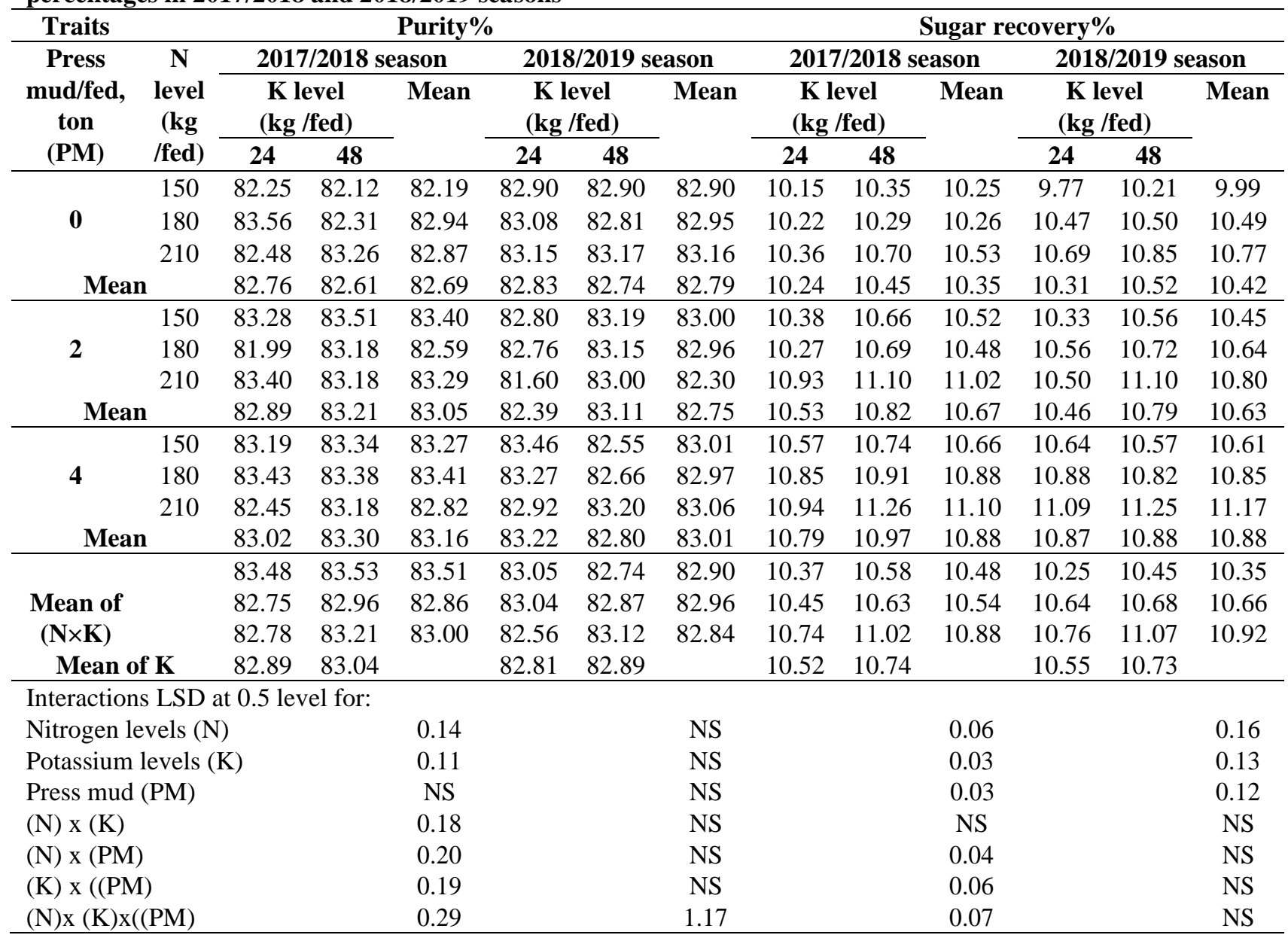

\section{Cane and sugar yields:}

The results in Table 7 revealed that increasing level of press mud supplied to sugarcane from 2 up to 4 tons/fed increased cane and sugar yields/fed significantly by (2.07 and 3.71 tons/fed) and (0.36 and 0.63 tons/fed), compared to those recorded without press mud, respectively, in the $1^{\text {st }}$ season, corresponding to (1.8 and 3.34 tons/fed) and (0.28 and 0.57 tons/fed), in the $2^{\text {nd }}$ one. These results could be referred to as the increase in the single stalk weight and a number of millable canes (Table 4) and juice quality characteristics as sucrose $\%$ (Table 5), purity $\%$ and sugar recovery $\%$ (Table 6) as affected by the applied press mud. These results are in agreement with those obtained by Pakkiyappan and Saminathan (1999), Kumar and Verma (2002), Babu et al., (2005), Shankaraiah and Murthy (2005), Santos et al., (2010), and Abd-El-Kader (2017).
The results in Table 7 pointed out that cane and sugar yields /fed were increased significantly by raising nitrogen fertilization level from 180 and to $210 \mathrm{~kg}$ $\mathrm{N} / \mathrm{fed}$ by (2.41 and 4.21 tons/fed) and ( 0.25 and 0.62 tons/fed) in the $1^{\text {st }}$ season, corresponding to (1.95 and 4.35 tons/fed) and (0.36 and 0.75 tons/fed) in the $2^{\text {nd }}$ one, compared to those produced by supplying canes with $150 \mathrm{~kg} \mathrm{~N} / \mathrm{fed}$. These results are probably referred to a positive effect of raising $\mathrm{N}$-levels given to sugarcane on growth traits, in respect to the single stalk weight and a number of millable canes (Table 4) and juice quality characteristics as sucrose \% (Table 5), purity $\%$ and sugar recovery $\%$ (Table 6 ). These results are in agreement with those reported by Santos et al., (2014), Girma Abejehu (2015), Ahmed and El-Shafai (2007), Mokadem et al., (2008), EL-Gedawwy et al., (2012) Neana and Abd El-Hak (2014) and Bekheet and Abd El-Aziz (2016). 
Data in the same table showed that cane and sugar yields were significantly affected by potassium application levels. The results cleared that applying 48 $\mathrm{kg} \mathrm{K}_{2} \mathrm{O} /$ fed produced the highest cane and sugar yields /fed, where increases of (51.12 and 50.86 tons/fed) and (5.53 and 5.48 tons/fed) in the $1^{\text {st }}$ and $2^{\text {nd }}$ season were gained, respectively compared to canes given $24 \mathrm{~kg}$ $\mathrm{K}_{2} \mathrm{O} / \mathrm{fed}$. These results are in line with those reported by El-Sogheir et al. (2003), Osman et al., (2004), Santos et al., (2010) and Santos et al., (2014).

In the same table, the interaction of $\mathrm{N} x \mathrm{~K}$ had a significant influence on cane yield /fed in the $2^{\text {nd }}$ season and sugar yield/fed in the $1^{\text {st }}$ one. The highest cane and sugar yields were produced when obtained by applying $210 \mathrm{~kg} \mathrm{~N} / \mathrm{fed}$ and $48 \mathrm{~kg} \mathrm{~K} \mathrm{~K}_{2} \mathrm{O} / \mathrm{fed}$. Cane and sugar yields were significantly affected by the interaction between $\mathrm{N}$ and press mud levels in both seasons. The highest yields of cane and sugar /fed were produced when 210 $\mathrm{kg} \mathrm{N}$ with 4 tons of press mud/fed were added. The interaction between potassium and press mud had a significant effect on cane yield/fed in the $2^{\text {nd }}$ season.
The highest yield of cane has been obtained with the addition of $24 \mathrm{~kg} \mathrm{~K}_{2} \mathrm{O}$ and 4 tons of press mud/fed. The $2^{\text {nd }}$ order interaction among the three studied factors had a significant effect on cane and sugar yields/fed in both seasons. Fertilization of sugar cane with $210 \mathrm{~kg} \mathrm{~N}$ $+48 \mathrm{~kg} \mathrm{~K}_{2} \mathrm{O}+4$ tons of press mud/fed gave the highest cane and sugar yields in the $1^{\text {st }}$ and $2^{\text {nd }}$ seasons.

Phenotypic correlations among yield and their traits:

Data in Table 8 showed that stalk height and diameter gave a positive and highly significant correlation with stalk diameter, cane yield (ton/fed), and sugar yield (ton/fed). Meanwhile, they gave a positive and non-significant correlation with the number of stalks and purity percentage. A positive association of cane length and diameter with cane yield has been reported by several investigators (Chaudhary et al., 2003, Singh and Sharma, 1997). A number of stalks showed positive and significant phenotypic correlations with each of cane yield and sugar yield.

Table 7 .Effect of press mud, nitrogen, potassium levels and their interactions on cane and sugar yields/fed in 2017/2018 and 2018/2019 seasons

\begin{tabular}{|c|c|c|c|c|c|c|c|c|c|c|c|c|c|}
\hline \multirow{4}{*}{$\begin{array}{c}\text { Traits } \\
\text { Press } \\
\text { mud/fed, } \\
\text { ton } \\
(\text { PM) }\end{array}$} & \multirow{4}{*}{$\begin{array}{c}\mathrm{N} \\
\text { level } \\
\text { (kg } \\
\text { /fed) }\end{array}$} & \multicolumn{6}{|c|}{ Cane yield ton /fed } & \multicolumn{6}{|c|}{ Sugar yield ton/fed } \\
\hline & & \multicolumn{3}{|c|}{$2017 / 2018$ season } & \multicolumn{3}{|c|}{ 2018/2019 season } & \multicolumn{3}{|c|}{$2017 / 2018$ season } & \multicolumn{3}{|c|}{$2018 / 2019$ season } \\
\hline & & \multicolumn{2}{|c|}{$\begin{array}{c}\begin{array}{c}\text { K level } \\
(\mathrm{kg} / \mathrm{fed})\end{array} \\
\end{array}$} & \multirow[t]{2}{*}{ Mean } & \multicolumn{2}{|c|}{$\begin{array}{c}\text { K level } \\
(\mathrm{kg} / \mathrm{fed})\end{array}$} & \multirow[t]{2}{*}{ Mean } & \multicolumn{2}{|c|}{$\begin{array}{c}\text { K level } \\
(\mathrm{kg} / \mathrm{fed})\end{array}$} & \multirow[t]{2}{*}{ Mean } & \multicolumn{2}{|c|}{$\begin{array}{c}\text { K level } \\
(\mathrm{kg} / \mathrm{fed})\end{array}$} & \multirow[t]{2}{*}{ Mean } \\
\hline & & 24 & 48 & & 24 & 48 & & 24 & 48 & & 24 & 48 & \\
\hline \multirow{3}{*}{$\mathbf{0}$} & 150 & 46.03 & 47.65 & 46.84 & 45.67 & 47.26 & 46.47 & 4.67 & 4.93 & 4.80 & 4.46 & 4.83 & 4.64 \\
\hline & 180 & 48.79 & 49.83 & 49.31 & 48.56 & 49.41 & 48.98 & 4.99 & 5.13 & 5.06 & 5.08 & 5.19 & 5.14 \\
\hline & 210 & 50.63 & 51.55 & 51.09 & 50.42 & 51.13 & 50.77 & 5.25 & 5.52 & 5.38 & 5.39 & 5.55 & 5.47 \\
\hline \multicolumn{2}{|c|}{ Mean } & 48.48 & 49.14 & 48.81 & 48.34 & 48.86 & 48.59 & 4.97 & 5.19 & 5.08 & 4.98 & 5.19 & 5.08 \\
\hline \multirow{3}{*}{2} & 150 & 48.69 & 49.30 & 48.99 & 47.84 & 48.60 & 48.22 & 5.05 & 5.26 & 5.15 & 4.94 & 5.13 & 5.03 \\
\hline & 180 & 50.60 & 51.71 & 51.16 & 49.62 & 50.75 & 50.19 & 5.20 & 5.53 & 5.36 & 5.24 & 5.44 & 5.34 \\
\hline & 210 & 52.31 & 53.27 & 52.79 & 51.88 & 53.65 & 52.77 & 5.72 & 5.91 & 5.82 & 5.45 & 5.96 & 5.70 \\
\hline \multirow[t]{2}{*}{ Mean } & & 50.53 & 51.22 & 50.88 & 49.78 & 51.00 & 50.39 & 5.32 & 5.57 & 5.44 & 5.21 & 5.51 & 5.36 \\
\hline & 150 & 50.19 & 51.57 & 50.88 & 49.06 & 51.07 & 50.07 & 5.31 & 5.54 & 5.42 & 5.22 & 5.40 & 5.31 \\
\hline \multirow[t]{2}{*}{4} & 180 & 51.76 & 52.92 & 52.34 & 50.74 & 52.14 & 51.44 & 5.62 & 5.77 & 5.69 & 5.52 & 5.64 & 5.58 \\
\hline & 210 & 54.14 & 54.53 & 54.33 & 53.61 & 54.93 & 54.27 & 5.92 & 6.14 & 6.03 & 5.95 & 6.18 & 6.06 \\
\hline \multicolumn{2}{|c|}{ Mean } & 52.03 & 53.01 & 52.52 & 51.14 & 52.71 & 51.93 & 5.62 & 5.82 & 5.71 & 5.56 & 5.74 & 5.65 \\
\hline \multirow{4}{*}{$\begin{array}{c}\text { Mean of } \\
(\mathbf{N} \times \mathbf{K}) \\
\text { Mean }\end{array}$} & 150 & 48.30 & 48.76 & 48.53 & 47.52 & 48.98 & 48.25 & 5.01 & 5.24 & 5.12 & 4.87 & 5.12 & 4.99 \\
\hline & 180 & 50.38 & 51.49 & 50.94 & 49.64 & 50.77 & 50.20 & 5.27 & 5.48 & 5.37 & 5.28 & 5.42 & 5.35 \\
\hline & 210 & 52.36 & 53.12 & 52.74 & 51.97 & 53.24 & 52.60 & 5.63 & 5.86 & 5.74 & 5.60 & 5.90 & 5.74 \\
\hline & f $\mathrm{K}$ & 50.35 & 51.12 & & 49.75 & 50.86 & & 5.30 & 5.53 & & 5.25 & 5.48 & \\
\hline \multicolumn{14}{|c|}{ Interactions LSD at 0.5 level for: } \\
\hline \multirow{2}{*}{\multicolumn{4}{|c|}{$\begin{array}{l}\text { Nitrogen levels }(\mathrm{N}) \\
\text { Potassium levels }(\mathrm{K})\end{array}$}} & 0.17 & & & 0.24 & & & 0.043 & & & 0.118 \\
\hline & & & & 0.16 & & & 0.069 & & & $0.031 *$ & & & $0.078^{*}$ \\
\hline \multicolumn{4}{|c|}{ Press mud (PM) } & 0.12 & & & 0.10 & & & 0.024 & & & 0.074 \\
\hline \multicolumn{4}{|c|}{$(\mathrm{N}) \times(\mathrm{K})$} & NS & & & 0.12 & & & 0.055 & & & NS \\
\hline \multicolumn{4}{|c|}{$(\mathrm{N}) \times(\mathrm{PM})$} & 0.19 & & & 0.18 & & & 0.042 & & & 0.127 \\
\hline$(\mathrm{K}) \times((\mathrm{PM}$ & & & & NS & & & 0.15 & & & NS & & & NS \\
\hline$(\mathrm{N}) \mathrm{x}(\mathrm{K}) \mathrm{x}($ & (PM) & & & 0.29 & & & 0.21 & & & 0.059 & & & 0.180 \\
\hline
\end{tabular}


Table 8. Phenotypic correlation coefficients among the yield and its components of sugar cane variety during two seasons

\begin{tabular}{|c|c|c|c|c|c|c|c|c|c|}
\hline Traits & 1 & 2 & 3 & 4 & 5 & 6 & 7 & 8 & 9 \\
\hline 1.Stalk Length & 1 & & & & & & & & \\
\hline 2. Stalk diameter & $0.972 * *$ & 1 & & & & & & & \\
\hline 3.Number of stalks & 0.722 & 0.446 & 1 & & & & & & \\
\hline 4. Stalk weight & $0.951 * *$ & $0.955^{* *}$ & 0.561 & 1 & & & & & \\
\hline 5. Brix\% & $0.744 *$ & $0.960 *$ & $0.778 *$ & $0.880 * *$ & 1 & & & & \\
\hline 6. Sucrose\% & $0.889 * *$ & $0.915^{*}$ & $0.833^{*}$ & $0.856 * *$ & $0.944 * *$ & 1 & & & \\
\hline 7. Purity \% & 0.013 & 0.008 & 0.167 & -0.028 & 0.156 & 0.112 & 1 & & \\
\hline 8. Sugar recovery \% & $0.889 *$ & $0.715^{*}$ & $0.833 *$ & $0.873 * *$ & $0.944 * *$ & $0.974 * *$ & 0.123 & 1 & \\
\hline 9. Cane yield & $0.954 * *$ & $0.972 * *$ & $0.722 * *$ & $0.986 * *$ & $0.944 * *$ & $0.889 * *$ & 0.009 & $0.889 * *$ & 1 \\
\hline 10. Sugar yield & $0.833 * *$ & $0.857 * *$ & $0.889 * *$ & $0.817 * *$ & $0.889 * *$ & $0.944 * *$ & 0.167 & $0.933 * *$ & $0.833 * *$ \\
\hline
\end{tabular}

$*$, ** Significant at $5 \%$ and $1 \%$ probability levels, respectively.

On the other hand, the number of stalks had a positive and non-significant correlation with stalk weight and purity percentage. Masri et al., (2015) found that a number of millable canes had negative correlations with all the other traits except cane yield. A strong negative correlation between cane weight and purity percentage was recorded. Cane yield (ton/fed) had a positive and highly significant correlation with sugar yield. However, such correlations were positive and insignificant with purity \%. Results are in agreement with those mentioned by Sanghera et al., (2015), they reported that cane yield correlated positivity with morphological and cane characters. The cane yield, considered as the most important character of sugarcane, had a positive correlation with sucrose\%, (Masri et al., 2015). Abu-Ellail et al., (2017) found that sucrose content in the juice was positively and significantly associated with sugar recovery percentage and sugar yield.

\section{CONCUSION}

Under conditions of the present work, supplying sugarcane with 4 tons of press mud/fed, added to the soil through seed-bed preparation, combined with 210 $\mathrm{kg}$ nitrogen (as urea) and $48 \mathrm{~kg} \mathrm{~K}_{2} \mathrm{O}$ (as potassium sulfate) can be recommended to get the highest cane and sugar yields/fed. The correlation analysis showed that the stalk diameter, number of stalks per meter, and weight of the cane contributed most to cane yield at the harvest.

\section{REFERENCES}

A.O.A.C. 1995. "Official methods of analysis", published by the A.O.A.C., Box, 540 Washington, D.C.

Abd El-Aal, A.M., S.R.E. El Shiekh and M.A. Fergany .2015. Ratooning ability of some sugarcane promising varieties under different levels of nitrogen fertilization. Egypt. J. Appl. Sci. 30 (1) :23-34.
Abd-El-Kader, M.F. 2017. Yield and physiological response of some new sugarcane cultivars to some cultural treatments. Ph.D. Thesis, Fac. of Agric., Assuit Univ., Egypt.

Abu-Ellail, F.F.B., A.B.A .El-Taib and M.I. Masri .2017. Broad-sense heritability, genetic correlation and genetic variability of sugarcane yield components at first selection stage. J. Sugarcane Res. 7 (1): 27 - 34.

Abu-Ellail, F.F.B., Y.M. Abd El-Azez, N.A. Bassiony .2019. Assessment of ratooning ability and genetic variability of promising sugarcane varieties under middle Egypt conditions. Electronic J. Plant Breed. 10(1):143-154.

Ahmed, Z.A. and A.M.A. El-Shafai .2007. Yield and quality of two sugarcane varieties as affected by bio and inorganic nitrogen fertilization. J. Agric. Sci. Mansoura Univ. 32(1):61-76.

Anonymous .1981. Chemical control in Egyptian sugar production factories. Jan., p.232.

Babu, M.V.S., C.M. Reddy, C.R. Kumari and T.Y. Reddy .2005. Effect of manure-fertilizer schedules on cane yield and leaf nutrient concentration at different growth phases of sugarcane (Saccharum officinarum L.). Journal of Research ANGRAU, 33(2) :27-34.

Barry, G.A., G.E. Rayment, A.J. Jefffery, and A.M. Price .2001. Changes in cane soil properties from application of sugar mill by-products. p. 185-In: Proceeding conference of the Australian society of sugarcane technology Mackay Queensland Australia.

Bekheet, M.A. and R.M. Abd El-Aziz .2016. Effect of row spacing, seed rate and nitrogen fertilization on yield and quality of sugarcane. J. Biol. Chem. Envirorn. Sci. 11(3): 605-619.

Chaudhary R.R., N.K. Chaudhary and R.C. Sharma.2003. Path coefficient analysis in sugarcane. J. Inst. Agric. Anim. Sci. 24: 13-19. 
El-Geddawy, I.H., A.O. El-Aref, M.M. Ibrahim and A.M.K. Ali .2012. Performance of some sugarcane varieties under nitrogen fertilization of sugarcane Succharum officinarum L. to the plant levels and harvesting dates. Egypt. J. of Appl. Sci. 27(12): 520-539.

El-Sayed, G.S., A.M.H. Osman and A.M. Ahmed .2005. Effect of nitrogen, phosphorus and potassium fertilization on yield and quality of sugar cane. Egypt, J. Agric. Res. 83(1): 241-257.

EL-Sayed,M.T., M.H. Babiker, M.E.Abdel- Malik, O.N. Mukhtar, and D. Montange .2008. Impact of filter mud application on the germin-ation of sugarcane and small seeded plants and on soil and sugarcane nitrogen contents. Biores Technol. 99: 181-186.

El-Soghier, K.S., A.M.H. Osman and G.S. El-Sayed .2003. Response of ratoon crop of some sugar cane varieties to different doses of phosphorus fertilization. Annuls of Agric. Sc. Moshtohor, 41(2): 489-501.

Falconer D.S .1989. Introduction to Quantitative Genetics. 3rd ed., Longman Scientific \& Technical, London. Pp 448

Freed, R.S.P., S.P. Eisensmith, S. Goetez, D. Recosky, V.W. Smail and P. Wolberg .1989. User's guide MSTAT-C software program for the design management and analysis of agronomic research experiments. Michingan State University, U.S.A.

Ghulam, S., M.J. Khan, K. Usman, and H. Rehman .2010. Impact of press mud as organic amendment on physicochemical characteristics of calcareous soil. Sarhad J Agric 26(4): 565-570.

Girma, A. .2015. Effect of filter cake and nitrogen fertilizer (Urea) on yield of sugarcane at Wonji-Shoa sugar estate scholarly. Journal of Agricultural Science, 5(4): 147-153.

Gomez, K.A. and A.A. Gomez .1984."Statistical Procedures for Agricultural Research", John Willey and Sons. Inc. New York.

Kalaimani, T. and S. Giridharan .2001. Effect of pressmud on the control of sugarcane sett rot caused by Ceratocystisparadoxa Moreau. Indian Sugar, 50(12): 863865.

Kumar, V. and K.S. Verma .2002. Influence of use of organic manure in combination with inorganic fertilizers on sugarcane and soil fertility. Indian. Sugar J. 52(3): 177181.

Masri M. I., Sh. A. Shaban, H. H. El-Hennawy, A. B. A. ElTaib and F.F.B. Abu-El-lail .2015. Phenotypic and genotypic correlations and path coefficient analysis sugarcane at first clonal selection stage. Egypt. J. Plant Breed. 19(2):297 - 321.

Mokadem, Sh.A., S.A.A. Atallah, M.A. Bekheet and A.F.I. Gadalla .2008. Effect of sources, levels and number of applications of nitrogen fertilizer on yield and quality of sugarcane. Minia J. Agric. Res. Develop. 28(4): 767-783.
Muhammad, D., and R.A. Khattak .2009. Growth and nutrient concentrations of maize in press mud treated saline-sodic soils. Soil Environ 28(2): 145-155.

Nassar, A.M., K.S. El-Sagheir, and B.S.H. Ramadan .2005. Effect of nitrogen levels on yield and juice quality of some sugar cane varieties. Egypt J. Agric. Res. 83(2):681-692.

Neana, Sh. M.M. and K.A.E. Abd El-Hak .2014. Effect of irrigation regime and nitrogen fertilization levels on sugarcane yield and its components. Alexandria Sci. Exchange J. 35(4): 288-294.

Osman, A.M.H., G.S. EL-Sayed, M.S.H. Osman and M.A. Bekheet .2004. Effect of planting density, mineral and biofertilizers of nitrogen and phosphorus on sugar cane productivity, Egypt. J. Agric. Res. 82(2): 697-716.

Pakkiyappan, P. and S. Saminathan .1999. Improvement of sugarcane production in tannery effluent polluted soils. Madras Agric. J. 86(4-6): 202-206.

Rangaraj, T., E.M. Somasundaram, M. Amanullah, V. Thirumurugan, S. Ram-Esh, and V. Ravi.2007. Effect of agro-industrial wastes on soil properties and yield of irrigated finger miller (Eleusine Coracana L. Gaertn) In Coastal Soil. Res J Agric Biol Sci 3 (3): 153-156.

Sanghera G.S., V. Tyagi, R. Kumar, K.S. Thind and B. Sharma .2015. Genetic variability, association and their dissection through path analysis for cane yield and its component traits in early maturing sugarcane clones. J. Sci. Agric. 5(1): 28-34.

Santos, D.H., C.S. Tiritan, J.S.S. Foloni, and L.B. Fabris .2010. Productivity of sugarcane under fertilization with filter cake enriched with soluble phosphate. Tropical Agric. Res. 40(4): 454-461.

Santos, D.H., M.D.A. Silva, C.S. Tiritan and C.A.C. Crusciol .2014. The effect of filter cakes enriched with soluble phosphorus used as a fertilizer on the sugarcane ratoons. Acta, Sci. Agron. 36(3): 365-372.

Shankaraiah, C. and K.K. Murthy .2005. Effect of enriched press mud cake on growth, yield and quality of sugarcane. Sugar Tech. 7(2-3): 1-4.

Singh, P. and M.L. Sharma .1997. Cause and effect of relationship in clonal population of sugarcane. 7th Seventh All India Congress of Cytology and Genetics, India. 25-32.

Solaimalai, A., M. Baskar, P.T. Ramesh, and N. Ravisankar .2001. Utilisation of press mud as soil amendment and organic manure - A review. Agric Rev 22(1): 25 - 32.

Wagner, G. P. and K. Schwenk. 2000. Evolutionarily stable configurations: Functional integration and the evolution of phenotypic stability. In M. K. Hecht, R. J. MacIntyre, and M. T. Clegg (eds.), Evolutionary biology, Vol. 31, pp. 155-217. Kluwer Academic/Plenum Press, New York. 


\title{
الملخص العربي
}

\section{الإرتباطات المظهرية وتكامُل التسميد النيتروجيني والبوتاسى وطينة المُرشِحات وعلاقته بحاصل وجودة قصب السكر}

\author{
أنور حامد ساسي و فرّاج فرغل برعى أبوالليل
}

أجريت هذه الدراسة فى محطة بحوث ملوى بمحافظة أوضحت النتائج المتحصل عليها أن زيادة التسميد

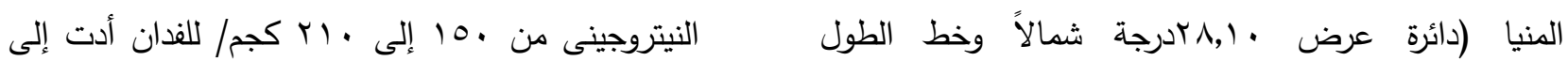

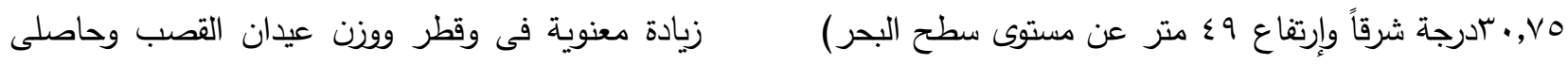

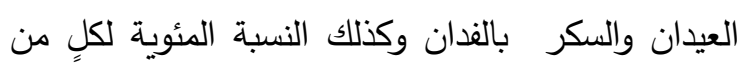

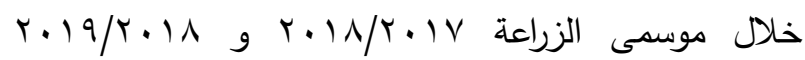
البركس والسكروز والنقاوة وناتج السكر النظرى في كلا لاراسة تأثير التسميد بطينة المرشحات كسماد عضوى، و و

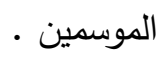
النيتروجين والبوتاسيوم غير العضوى علي انتاجية وجودة - أدت إضافة البوتاسيوم بمعدل ^ء كجم/ للفدان لزيادة

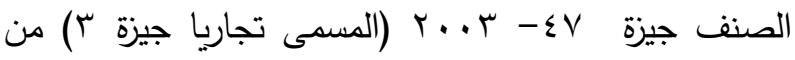
معنوية في طول وقطر وعدد عيدان القصب وحاصلى الفدان من العيدان والسكر وأيضاً النسبة المئوية للبركس وعن وفيل والسكروز وناتج السكر النظرى في كلا الموسمين. تحت ظروف هذه الدراسة، يمكن التوصية بتسميد قصب السكر بإضافة طينة المرشحات أثناء تجهيز التربة للزراعة

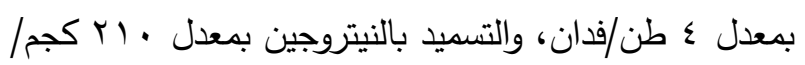

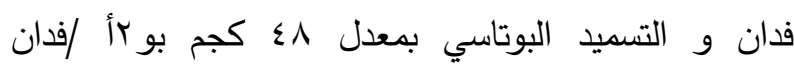
للحصول على أعلي إنتاجية من العيدان والسكر للفدان. أظهر تحليل الارتباط أن قطر العود وعدد السيقان للمتر ووزن العود ساهم بشكل كبير في إنتاجية محصول قصب السكر. تم تصميم التجربة بنظام القطع كاملة العشوائية فى توزيع القطع المنشقة مرتين في ثلاث مكررات

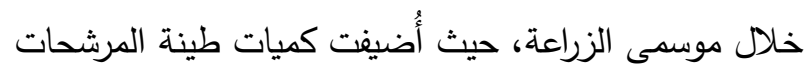

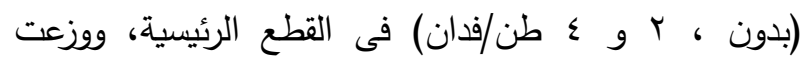

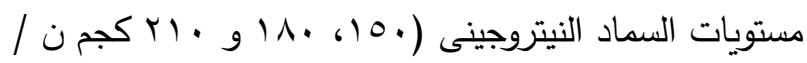
فدان) فى القطع الثقية الأولى ، وشغل مستويى البوتاسيوم

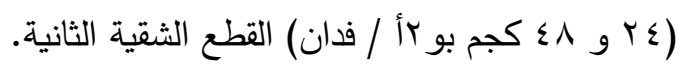
- أعطى استخدام المخصب العضوى (طينة المرشحات) زيادة معنوية في طول وقطر النبات وعدد العيدان ووزن العود وحاصلى العيدان والسكر بالفدان، وكذلك نسبة

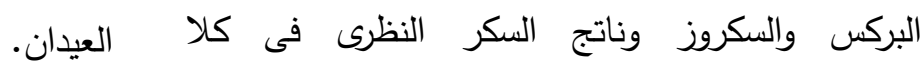

